\title{
Correlation of histopathological patterns in cutaneous melanoma with BRAF mutations
}

Primeira submissão em 25/06/10 Última submissão em 28/08/10 Aceito para publicação em 29/09/10 Publicado em 20/12/10

\section{Correlação de padrões histopatológicos de melanomas cutâneos com mutações BRAF}

Juliana Elizabeth Jung'; Jorge Eduardo Fouto Matias²; Norbert Blödorn-Schlicht'; ${ }^{3}$ Thomas M. Falk; Almut Böer

key words

Malignant melanoma

Proto-oncogene proteins BRAF

Histolopathology

\section{abstract}

Introduction: Mutations on BRAF gene located on chromosome $7 q$ are the most frequently found in cutaneous melanomas (60\%-80\%). The only study correlating histopathological patterns of cutaneous melanomas with the presence of BRAF mutations was undertaken by Viros et al. in 2008. The authors observed that morphological features of melanomas are associated with BRAF mutations. Objectives: To correlate histopathological patterns in cutaneous melanoma with the presence of BRAF mutations in order to corroborate the results of the study performed by Viros et al. Methods: Paraffin embedded surgical specimens of 20 primary cutaneous melanomas with BRAF mutation and 20 specimens without BRAF mutation were evaluated independently by two dermatologists that carried out a blind experiment. The features analyzed were nesting, circumscription, presence of isolated melanocytes in the lesion, size and shape of neoplastic cells, and tumor cell pigmentation. Results: "Nesting" was the most prevalent variable for the determination of melanomas with BRAF mutations according to both observers $(r=0.46 ; p=0.04)$. Conclusion: As far as mutational status is concerned, it was not possible to confirm any predictive value for histopathological patterns such as circumscription, presence of isolated melanocytes in the lesion and cytological features. Difficulties in the interpretation of some histological criteria were demonstrated by the variation in the observers' conclusions. It is difficult to state if genetic alterations such as BRAF mutations may serve as biomarkers for melanoma classification.

\footnotetext{
Introdução: Mutações do gene BRAF localizado no cromossomo $7 q$ são as mais frequentemente encontradas em melanomas cutâneos (60\%-80\%). O único estudo que correlacionou padrões histopatológicos de melanomas cutâneos com a presença de mutações BRAF foi realizado por Viros et al., em 2008, que observaram que características morfológicas de melanomas estavam associadas a mutações BRAF. Objetivos: Correlacionar padrões histopatológicos de melanomas cutâneos com a presença de mutações BRAF, a fim de confirmar os achados de Viros et al. Métodos: Espécimes em parafina de 20 casos de melanomas cutâneos primários com mutações BRAF e 20 casos sem mutações foram avaliados independentemente por dois dermatologistas sem o conhecimento da presença ou não das mutações. Os padrões analisados foram formação de "ninhos", circunscrição, presença de melanócitos isolados na lesão, tamanho e forma das células neoplásicas e pigmentação das células tumorais. Resultados: A formação de "ninhos" foi a variável com o maior poder de determinação para melanomas com mutações BRAF para ambos os observadores $(r=0,46$; $\mathrm{p}=0,04)$. Conclusão: Não foi possível confirmar nenhum valor preditivo em relação ao status mutacional de um melanoma para os padrões histológicos circunscrição e presença de melanócitos isolados na lesão, bem como para características citológicas. Dificuldades na interpretação de alguns critérios histológicos foram demonstradas pela variação da concordância entre os observadores. É difícil afirmar se alterações genéticas como as mutações BRAF podem servir como biomarcadores para a classificação de melanomas.
}

1. Doutora em Clínica Cirúrgica pela Universidade Federal do Paraná (UFPR).

2. Doutor em Cirurgia Digestiva pela Universidade de Montpellier (França); professor adjunto da UFPR.

3. Doutor em Dermatologia pela Universidade de Frankfurt (Alemanha); dermatopatologista do Instituto Dermatologikum Hamburg (Alemanha).

4. Doutor em Biologia pela Universidade de Hamburgo (Alemanha); biólogo do setor de Biologia Molecular do Instituto Dermatologikum Hamburg (Alemanha).

5. Doutora em Dermatologia pela Universidade de Frankfurt (Alemanha); dermatopatologista do Instituto Dermatologikum Hamburg (Alemanha).

0 presente estudo faz parte da tese de doutorado em Clínica Cirúrgica de Juliana Elizabeth Jung, UFPR. 


\section{Introduction}

The current World Health Organization (WHO) has classified the melanomas in four types, namely, superficial spreading, lentigo maligna, nodular, and acral lentiginous( ${ }^{(6)}$. However, controversy remains as to whether these variations reflect inherent biologic differences or secondary effects that depend on the skin architecture of different anatomic sites $^{(8)}$. The first to call this classification into question was Ackerman, who considered all malignant melanomas to evolve in a similar way: all are at first horizontally (superficially) spreading within the epidermis and all may eventually extend vertically into the dermis. This repetitive sequence of histological changes in melanoma is accompanied by equally repetitive clinical features at all anatomic sites. Some clinical features, however, are more common on certain anatomic site than others ${ }^{(1)}$.

Recently molecular biology techniques have permitted the identification of molecular markers involved in melanoma pathogenesis such as the BRAF gene. Mutations on the BRAF gene located on chromosome $7 q$ are the most frequent mutations $(60-80 \%)$ found in human melanomas. The BRAF gene encodes a serine/threonine kinase downstream of RAS in the RAS/RAF/MAPK pathway that is involved in transduction of mitogenic signals from membrane receptors to the nucleus ${ }^{(3)}$.

The only study correlating histomorphological patterns of melanomas closely with BRAF mutations was undertaken by Viros et al., in 2008. The authors showed that distinctive morphological features of cutaneous melanoma, such as increased upward migration, nest formation of intraepidermal melanocytes, thickening of the involved epidermis, sharper demarcation to the surrounding skin, and larger, rounder, and more pigmented tumor cells, seem to be associated consistently with BRAF mutations. The authors suggested that a genetically refined morphological classification of primary melanomas may improve existing melanoma classifications by forming subgroups that are genetically more homogeneous and likely to differ in important clinical variables such as outcome and pattern of metastasis ${ }^{(14)}$. The authors admitted, however, that their results needed to be confirmed in independent samples and in regard to interobserver agreement in the assessment of morphological features.

In this study, we attempted to correlate the assessment of histopathological patterns in cutaneous melanoma with the presence of BRAF mutations in order to reassess the results of Viros et al. especially in regard to interobserver agreement.

\section{Material and methods}

A total of 40 cases of primary cutaneous melanoma were included in this study. Twenty cases with BRAF mutation and 20 cases without BRAF mutation were compared.

\section{Molecular genetic analysis}

Parafin embedded tumor material (about $1 \mathrm{~mm}^{2}$ ) was semi-microdigested from $10 \mu \mathrm{m}$ sections using 1-2 $\mu \mathrm{l}$ of digestion buffer $(10 \mu \mathrm{l}$ Proteinase K/90 $\mu \mathrm{l}$ 1x PCR buffer; QIAGEN). After about 15 minutes, digestions of these crude extracts were subsequently completed within a total volume of $100 \mu$ incubated at $55^{\circ} \mathrm{C}$ for at least $24 \mathrm{~h}$. After Proteinase $\mathrm{K}$ inactivation $\left(95^{\circ} \mathrm{C} / 8 \mathrm{~min}\right.$.) enriched tumor DNA samples were used directly in subsequent genetic studies. The same procedure was also used to prepare DNA samples from non-tumor sites. Pathological review was performed on all specimens using HE-stained slides for comparison. Primarily, TaqMan RT-PCR detection was used to identify BRAF V600E mutations modified according to Smyth et al. ${ }^{(12)}$. Primers and probes were as follows: BRAFFor: 5'-CATGAAGAC CTCACAGTAAAAATAGGTGAT-3'; BRAF-Rev: 5'-GGATCCAGACA ACTGTTCAAACTGA-3'; HEX5'-CCATCGAGATTTCACTGTAG-3'-TAMRA (BRAF-WT); FAM5'-CCATCGAGATTTCTCTGTAG-3'-TAMRA (BRAF-V600E -MUT). Amplification and RT-PCR analysis was performed on an IQ5-Cycler (BioRad Laboratories, Inc.) for 50 cycles $\left(95^{\circ} \mathrm{C}\right.$ for $3 \mathrm{~min}$. [1 cycle]; $95^{\circ} \mathrm{C}$ for $15 \mathrm{~s}, 59^{\circ} \mathrm{C}$ for $1 \mathrm{~min}[50$ cycles]). RT-PCR reactions were carried out in $25 \mu$ reaction mixtures: 1x IQ Supermix (BioRad Laboratories, Inc.), $500 \mathrm{nM}$ of each primer, $200 \mathrm{nM}$ of each probe and about $40-90 \mathrm{ng}$ total DNA (final concentrations). Each sample was analysed twice. Results of RT-PCR analyses were also verified by direct sequencing of BRAF exon 15 PCR products (6 BRAF V600E positive and 20 BRAF V600E negative samples). Amplification of Exon 15 was carried out according to Davis et al.(3): exon 15- For: 5'-TCATAATG CTTGCTCTGATAGGA-3'; exon 15Rev: 5'-GGCCAAAAATTAATCAGTGGA -3'. PCR reactions were performed in $50 \mu \mathrm{l}$ reaction mixtures (1x reaction buffer, HotStarTaq QIAGEN; $3.5 \mathrm{mM} \mathrm{MgCl} ; 1.2 \mu \mathrm{M}$ of each primer; about $40-60 \mathrm{ng}$ total DNA; $200 \mu \mathrm{M}$ of each dNTP; 2.5 units HotStarTaq DNA polymerase, QIAGEN). The thermal profile was: $1.95^{\circ} \mathrm{C} / 15 \mathrm{~min}(1 \mathrm{cycle}) ; 2.94^{\circ} \mathrm{C} / 20 \mathrm{~s}$; $56^{\circ} \mathrm{C} / 30$ s; $72^{\circ} \mathrm{C} / 30$ s (50 cycles); $3.72^{\circ} \mathrm{C} / 8$ min ( 1 cycle). PCR products were purified (GFX PCR DNA and Gel Band Purification Kit (GE Healthcare, UK)) and sequenced on an ABI 377 automated sequencer (Applied Biosystems) using the BigDye Terminator Cycle Sequencing Chemistry (Applied 
Biosystems). Sequences were further processed using BioEdit version 5.0.9 and identified using the NCBI BLAST search. Samples for which insufficient, no or only BRAF-V600E -WT fluorescence signals (HEX) were obtained by RT-PCR assays were amplified according to Davis et al. and subsequently sequenced (BRAF exon 15) $)^{(3)}$.

\section{Histopathological patterns}

All histopathological evaluations were carried out independently on routinely stained HE sections by two dermatopathologists. The criteria used to examine the histopathological features were as follows:

- nesting: intraepidermal melanocytes were defined as arranged in nests rather than single cells if they formed clusters of five or more cells whether located in the basal epidermis or in higher layers of the epidermis and classified as:

$\sqrt{ }$ nests predominant: more than $25 \%$ of the melanocytes arranged in nests (Figure 1A);

$\sqrt{ }$ nests not predominant: intraepidermal melanocytes present almost exclusively as single cells with only rare nests or with no more than $25 \%$ of cells in nests (Figure 1B);

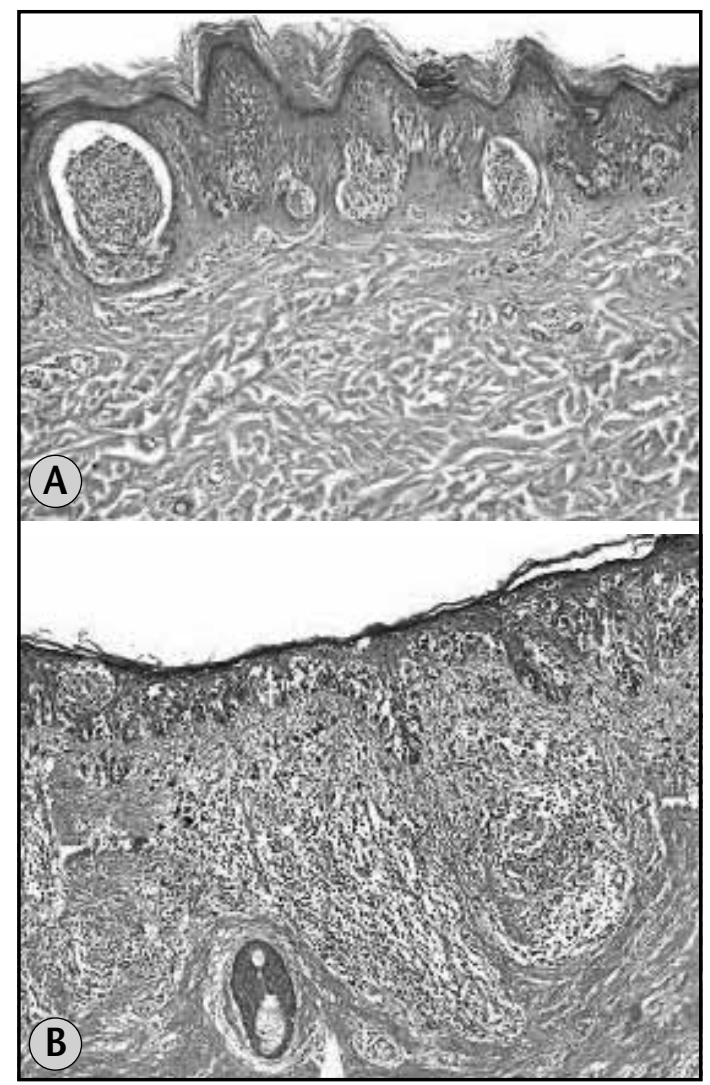

Figure 1 - (A) Melanoma with predominance of nests HE 10x; (B) melanoma with predominance of single cells HE $10 x$
- circumscription: lateral circumscription was assessed by examining the transition of the intraepidermal growth portion of the tumor to normal skin at the tumor periphery:

$\sqrt{ }$ well circumscribed: when transition from involved epidermis to adjacent normal skin was abrupt and easily determined within one or two rete ridges (Figure $\mathbf{2 A}$ );

$\sqrt{ }$ poorly circumscribed: continuous decrease of the number of intraepidermal melanocytes making it difficult to establish the transition too normal skin (Figure 2B);

- scatter of intraepidermal melanocytes: the proportion of intraepidermal melanocytes present above the basal layer was assessed as:

$\checkmark$ scatter predominant: when equal proportions of intraepidermal melanocytes present at the dermo-epidermal junction and in higher epidermal layers or most (>50\%) of the intraepidermal melanocytes situated in the upper layers of the epidermis (Figure $\mathbf{3 A}$ );

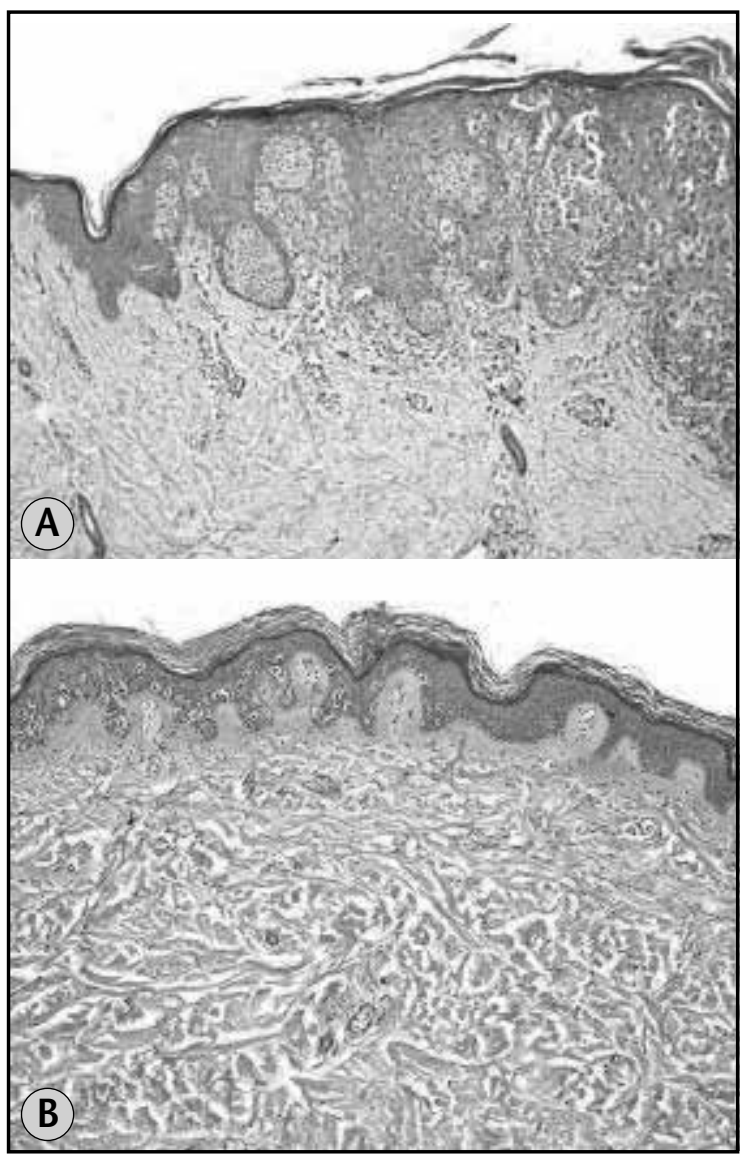

Figure 2 - (A) Well circumscribed melanoma HE 10x; (B) poorly circumscribed melanoma HE $10 x$ 
$\sqrt{ }$ scatter not predominant: essentially all melanocytes situated at the dermo-epidermal junction, with only rare melanocytes in higher epidermal layers or the majority of melanocytes (75\%-100\%) situated at the dermo-epidermal junction, with some present in higher epidermal layers (Figure 3B);

- size and shape of tumor cells and nuclei : these features were assessed in the most cellular portion of the tumor using a 20X lens. Nuclei of small lymphocytes were used as a size reference. Tumor cells were considered:

$\sqrt{ } 1$ : small if the greatest diameter was $<10 \mu \mathrm{m}$ (Figure 4A);

$\sqrt{ }$ 2: large if the greatest diameter was $>10 \mu \mathrm{m}$ (Figure 4B).

- Similarly, nuclei were considered:

$\sqrt{ } 1$ : small if the greatest diameter was $<6 \mu \mathrm{m}$ (Figure 4A)

$\sqrt{ } 2$ : large if the greatest diameter was $>6 \mu \mathrm{m}$ (Figure 4B);

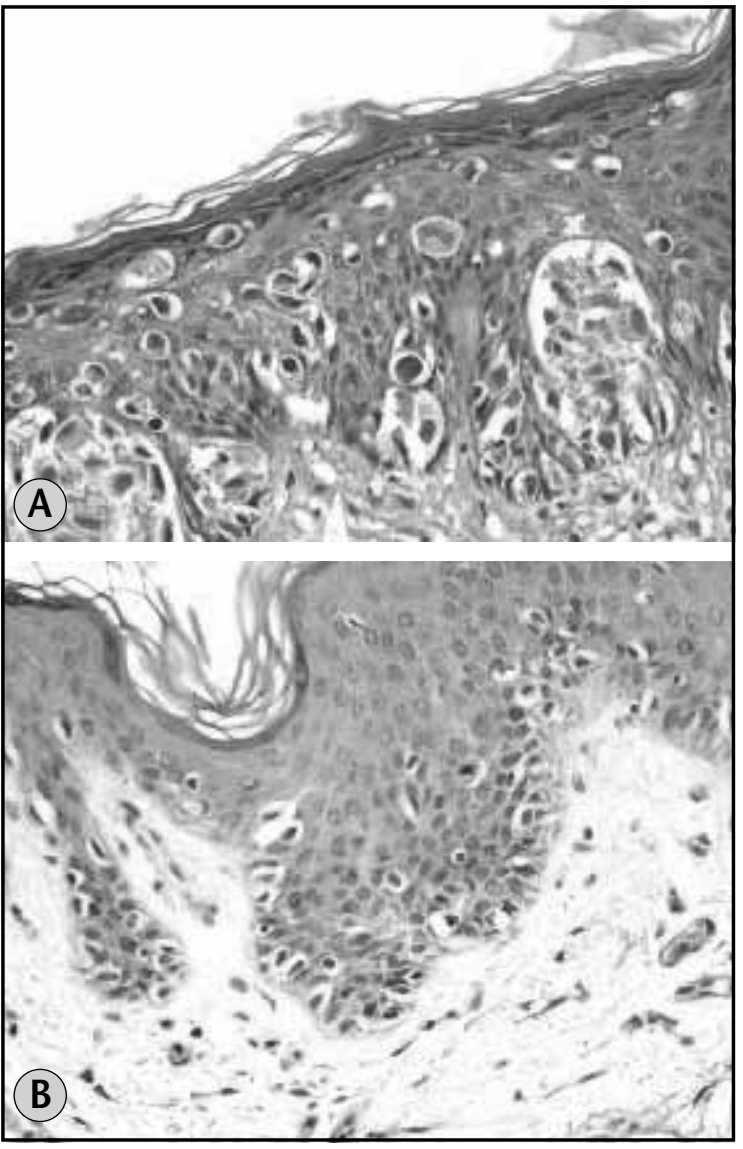

Figure 3 - (A) Melanoma with predominance of scattered melanocytes HE 20x; (B) melanoma with melanocytes situated at the dermo-epidermal junction HE 20X
- tumour cell pigmentation: maximum pigmentation scored anywhere in the tumor. Pigmentation was scored from 1 or 2 :

$\sqrt{ }$ 1: absent or moderate;

$\sqrt{ }$ 2: high (Figure 5).

\section{Statistical analysis}

Interobserver agreement was estimated by the kappa coefficient of agreement as follows:

- < 0, 20: poor agreement;

- 0, 21-0, 4: fair agreement;

- 0, 41-0, 6: moderate agreement;

- 0, 61-0, 8: good agreement;

- 0, 81-1: very good agreement.

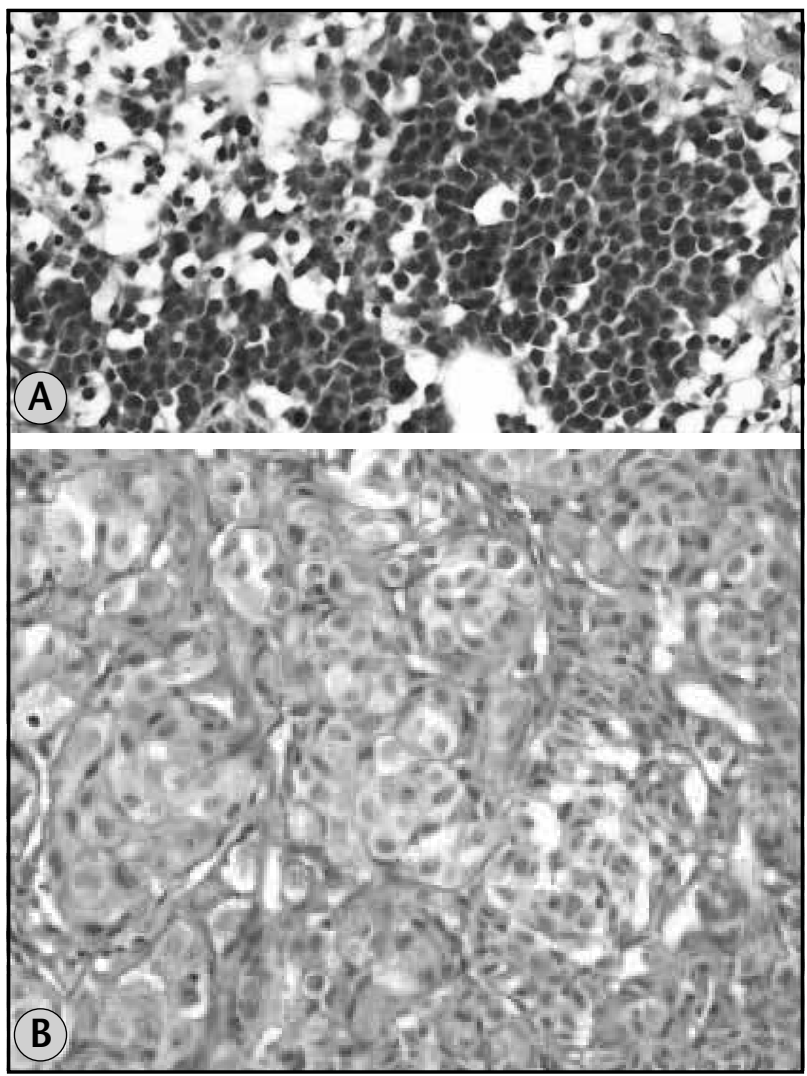

Figure 4 - (A) Melanoma with small cells and small nuclei HE 40x; (B) melanoma with large cells and large nuclei HE 40X

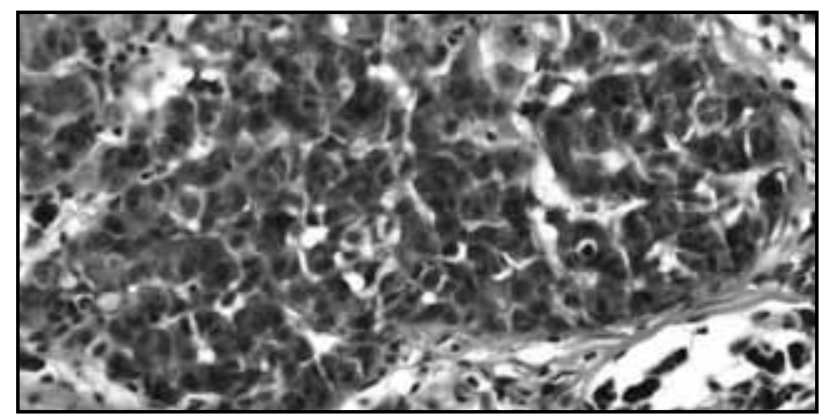

Figure 5 - Heavily pigmented melanoma HE 40x 
Fischer's exact test was applied to estimate the correlation of morphological features with presence of BRAF mutation. Odds ratio was used to estimate the risk of mutation according to the morphological features. The multivariate logistic regression model was applied to identify which morphological feature was the most powerful one to determinate the presence of BRAF mutation. Two-sided tests were applied and the significance level was 5\%. The sample size was estimated considering an alpha error (type I) of $5 \%$ and an alpha error (type II) of $10 \%$, with the estimated power of the test of $90 \%$.

\section{Results}

This study analyzed 40 specimens of cutaneous melanoma, 20 BRAF mutated and 20 BRAF wild-type. Four morphological features were evaluated independently by two dermatopathologists (A and J) blinded to the knowledge of the genetic status of the tumors. According to the conventional melanoma classification, 29 were superficial spreading and 11 nodular melanomas. Seventeen superficial spreading melanomas and three nodular melanomas presented the BRAF mutation.

There was good interobserver agreement for the histological pattern of "nesting" (kappa coefficient = $0,7)$. For the morphologic feature "circumscription" the interobserver agreement was also good (kappa coefficient $=0,74)$. For the patterns "scatter of melanocytes", "cell size", "size of nuclei" and "tumour cell pigmentation" the interobserver agreement was moderate (kappa coefficient $=0,49 ; 0,54 ; 0,54$ and 0,58 , respectively).

Table 1 summarizes the frequency ( $n$ and \%) of the morphologic features evaluated by the two observers according to the presence of BRAF mutations. The odds ratio of BRAF mutation according to the morphological features and the observers is given in Table 2.

Table 1 Morphologic features of Melanomas by Mutation Status of BRAF

\begin{tabular}{|c|c|c|c|c|c|}
\hline Morphological features & Observer & Category & BRAF present & BRAF absent & $p$ \\
\hline \multirow{2}{*}{ Nesting } & A & $\begin{array}{l}\text { Predom. } \\
\text { Not. }\end{array}$ & $\begin{array}{l}14(73.4) \\
6(28.6)\end{array}$ & $\begin{array}{l}5(26.3) \\
15(71.4)\end{array}$ & 0.01 \\
\hline & J & $\begin{array}{l}\text { Predom. } \\
\text { Not. }\end{array}$ & $\begin{array}{l}16(69.6) \\
4(23.5)\end{array}$ & $\begin{array}{l}7(30.4) \\
13(76.5)\end{array}$ & $<0.01$ \\
\hline \multirow{2}{*}{ Circumscription } & A & $\begin{array}{l}\text { Well } \\
\text { Poor }\end{array}$ & $\begin{array}{l}11(64.7) \\
9(39.1)\end{array}$ & $\begin{array}{l}6(35.3) \\
14(60.9)\end{array}$ & 0.2 \\
\hline & J & $\begin{array}{l}\text { Well } \\
\text { Poor }\end{array}$ & $\begin{array}{l}11(61.1) \\
9(40.9)\end{array}$ & $\begin{array}{l}7(38.9) \\
13(59.1)\end{array}$ & 0.34 \\
\hline \multirow{2}{*}{ Scatter } & A & $\begin{array}{l}\text { Predom. } \\
\text { Not. }\end{array}$ & $\begin{array}{l}11(52.4) \\
9(47.4)\end{array}$ & $\begin{array}{l}10(47.6) \\
10(52.6)\end{array}$ & 1 \\
\hline & J & $\begin{array}{l}\text { Predom. } \\
\text { Not. }\end{array}$ & $\begin{array}{l}14(51.8) \\
6(46.1)\end{array}$ & $\begin{array}{l}13(48.2) \\
7(53.8)\end{array}$ & 1 \\
\hline \multirow{2}{*}{ Cell size } & A & $\begin{array}{l}1 \\
2\end{array}$ & $\begin{array}{l}3(50 \%) \\
17(50 \%)\end{array}$ & $\begin{array}{l}3(50 \%) \\
17(50 \%)\end{array}$ & 1 \\
\hline & J & $\begin{array}{l}1 \\
2\end{array}$ & $\begin{array}{l}4(57.4 \%) \\
16(48.5 \%)\end{array}$ & $\begin{array}{l}3(42.8 \%) \\
17(51.1 \%)\end{array}$ & 1 \\
\hline \multirow{2}{*}{ Nuclei size } & A & $\begin{array}{l}1 \\
2\end{array}$ & $\begin{array}{l}3(50 \%) \\
17(50 \%)\end{array}$ & $\begin{array}{l}3(50 \%) \\
17(50 \%)\end{array}$ & 1 \\
\hline & J & $\begin{array}{l}1 \\
2\end{array}$ & $\begin{array}{l}3(42.8 \%) \\
17(51.5 \%)\end{array}$ & $\begin{array}{l}4(57.2 \%) \\
16(48.5 \%)\end{array}$ & 1 \\
\hline \multirow{2}{*}{ Pigmentation } & A & $\begin{array}{l}1 \\
2\end{array}$ & $\begin{array}{l}12(63.2 \%) \\
8(38.1 \%)\end{array}$ & $\begin{array}{l}7(36.8 \%) \\
13(61.9 \%)\end{array}$ & 0.2 \\
\hline & J & $\begin{array}{l}1 \\
2\end{array}$ & $\begin{array}{l}7(41.2 \%) \\
12(54.5 \%)\end{array}$ & $\begin{array}{l}10(58.8 \%) \\
10(45.5 \%)\end{array}$ & 0.52 \\
\hline
\end{tabular}

Fisher exact's test. 
Table 2 Morphologic features of melanomas by mutation status of BRAF

\begin{tabular}{lclc}
\hline $\begin{array}{l}\text { Morphological } \\
\text { features }\end{array}$ & $\begin{array}{c}\text { Observer } \\
\text { Observer }\end{array}$ & $p$ \\
Nesting & A & $\begin{array}{l}7(1.7-28.2) \\
\text { Jds ratio }\end{array}$ & 0.01 \\
& J & $7.4(1.8-31)$ & $<0.01$ \\
Circumscription & & $\begin{array}{l}2.8(0.8-10.5) \\
2.3(0.6-8.1)\end{array}$ & 0.11 \\
& & 0.20 \\
Scatter & A & $1.2(0.3-4.2)$ & 0.75 \\
& J & $1.2(0.3-4.7)$ & 0.73 \\
Cell size & A & $1(0.2-5.7)$ & 1 \\
Nuclei & J & $1.4(0.3-7.3)$ & 1 \\
size & A & $1(0.2-5.7)$ & 1 \\
Pigmentation & J & $1.4(0.3-7.3)$ & 1 \\
& A & $2.8(0.8-10)$ & 0.2 \\
& J & $0.6(0.2-2.1)$ & 0.52 \\
\hline
\end{tabular}

The multivariate logistic regression analysis, considering BRAF mutation as a dependent variable and the morphologic features as the independent variables, showed that "nesting" was the variable with highest power of determination for melanomas with BRAF mutations $(r=0,46 ; p=0,04)$ for both observers.

\section{Discussion}

BRAF represents the most common oncogene mutated in melanoma and according to some authors it is the most important biomarker for this tumour ${ }^{(2)}$. The frequency of BRAF mutations significantly exceeds the frequency of known mutations of other major genes in cutaneous malignant melanomas, such as N-Ras, p16, and p53(11), however, it is not clear, whether BRAF gene mutations are associated with progression of melanoma ${ }^{(5)}$. The frequent occurrence of BRAF mutations in melanoma suggests that specific BRAF inhibitors could be useful therapeutic agents for advanced melanoma ${ }^{(8)}$ and an improved classification of melanomas that combines an analysis of known genetic factors with histomorphological features might divide melanomas into subgroups that are likely to differ in terms of their clinical outcome and responses to target therapies when they become available ${ }^{(14)}$.

$A$ recent study showed that melanomas with BRAF mutations presented with an increased upward migration and nest formation of intraepidermal melanocytes, thickening of the involved epidermis, and sharper demarcation to the surrounding skin, and they had larger, rounder, and more pigmented tumor cells ${ }^{(14)}$. According to the authors, using simple combinations of features, BRAF mutation status could be predicted with up to $90,8 \%$ accuracy in the entire cohort of 302 specimens, as well as with the categories of the current WHO classification ${ }^{(14)}$.

Despite numerous studies that correlate the presence of BRAF mutations with clinical and prognostic histopathological data in cutaneous melanoma $a^{(4,7,9,10,11,13)}$ no other studies attempted to correlate the presence of these mutations with histopathological criteria used for diagnosis of melanoma.

In our study, we tried at first to use the same quantitative classification of criteria as suggested by Viros et al., but the application of these criteria turned out to be very subjective. We found it particularly difficult to classify the presence of intraepidermal melanocytes and scatter of melanocytes into four categories, as well as lateral circumscription into three categories. Therefore, we decided to simplify the classification as given in the section on Methods in this article. Nevertheless, it remained difficult to analyze scatter when the epidermis was very thin (Figure 6) or ulcerated (Figure 7) and to judge predominance of nests or single melanocytes when the tumor was composed largely of sheets of melanocytes.

In the study by Viros et al., interobserver agreement was determined by having an additional observer score in a randomly selected subset of 50 cases. The authors stated in their article that Kappa statistics indicated moderate to excellent interobserver agreement. The data provided by them shows, however, that Kappa coefficient ranged from 0.4 for circumscription, over 0.6 for nesting and 0.7 for scatter to 0.8 for solar elastosis. According to our criteria, interobserver agreement in their study ranged from fair (for circumscription and nesting) over moderate (for scatter) to good (only for the presence of sun damage).

In our own study, all cases were analyzed independently by two dermatopathologists and the coefficient of agreement ranged from 0.49 (for scatter), 0.54 (for cell size and nuclei size) over 0,58 (for tumour cell pigmentation) and 0.7 (for nesting) to 0.74 (for circumscription), indicating that the interobserver agreement was either moderate or good, but never excellent.

Prominent nesting was the only morphological feature, which was significantly associated with BRAF mutations for both observers. This feature found in a melanoma rises the risk for BRAF mutations 7 times (odds ratio $=7[\mathrm{~A}]$; odds ratio $=7,4[]]$ ), although the confidence interval was broad, considering the sample size. Nesting was identified as the 


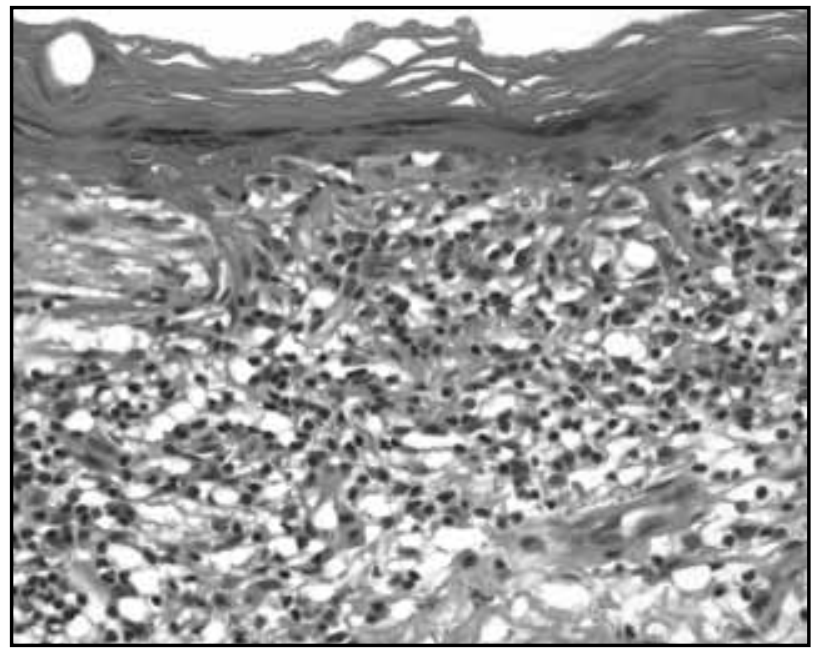

Figure 6 - Melanoma with epidermal atrophy HE 20x

feature with highest power of determination for the presence of BRAF mutation by multivariate logistic regression analysis, but the coefficient of determination was moderate.

Although our results show that predominance of nests over single melanocytes suggests the presence of BRAF mutations and that prominent nesting raises the risk for BRAF mutations around 7 times, too few cases were analyzed to interpret this finding as definitive. We could not confirm

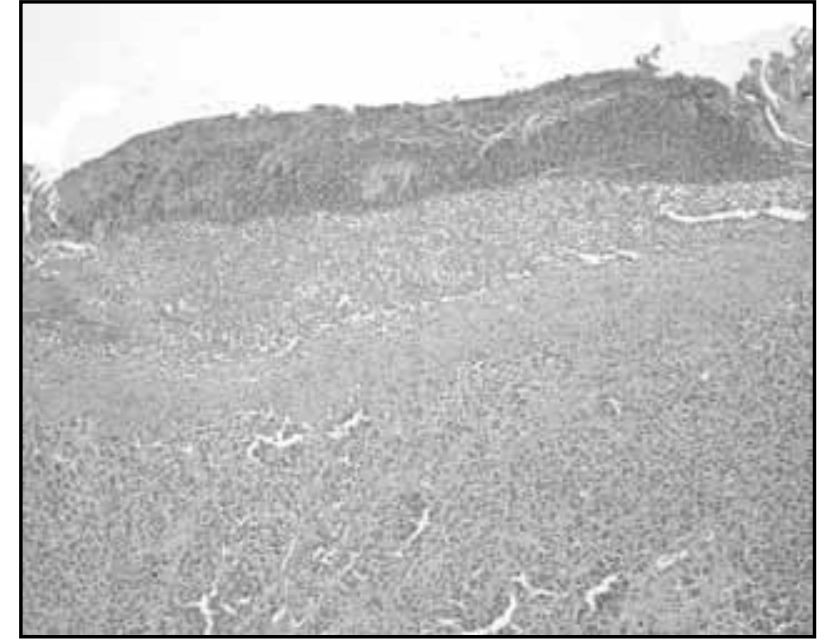

Figure 7 - Ulcerated melanoma HE 20x

any predictive value in regard to BRAF mutational status of a melanoma for the histopathological patterns of scatter, circumscription, size of cells or nuclei and pigmentation. Difficulties in the interpretation of some criteria were demonstrated by the variation in the interobserver agreement. At this point, it is difficult to state whether genetic alterations such, as BRAF mutations can serve as biomarkers for classification of melanoma.

\section{References}

1. ACKERMANN, A. B. Malignant melanoma. A unifying concept. Am J Dermatopatol, v. 2, n. 4, p. 309-13, 1980.

2. CHIN, L.; GARRAWAY, L. A; FISHER, D. E. Malignant melanoma: genetics and therapeutics in the genomic era. Genes \& Development, v. 20, p. 2149-82, 2008.

3. DAVIES, $H$. et al. Mutations of the BRAF gene in human cancer. Nature, v. 417, p. 949-54, 2002.

4. DEICHMANN, M. et al. B-raf exon 15 mutations are common in primary melanoma ressection specimens but not associated with clinical outcome. Oncology, v. 66, p. 411-9, 2004.

5. DONG, J. et al. BRAF oncogenic mutations correlate with progression rather than initiation of human melanoma. Cancer Research, v. 63, p. 3883-5, 2003.

6. LEBOIT, F. E. et al. World Health Organization classifications of tumors: pathology and genetics of skin tumors. Lyon: IARC Press, 2006. p. 49-78.

7. LIU, W. et al. Distinct clinical and pathological features are associated with the BRAF T1799A (V600E) mutation in primary melanoma. J Invest Dermatol, v. 127, p. 901-5, 2007.

8. MALDONADO, J. L. et al. Determinants of BRAF mutations in primary melanomas. J Nat Cancer Inst, v. 95, n. 24, p. 1878-80, 2003.

9. OMHOLT, K. et al. NRAS and BRAF mutations arise early during melanoma pathogenesis and are preserved throughout tumor progression. Clin Cancer Res, v. 9 , n. 15, p. 6483-8, 2003.

10. SALDANHA, G. et al. Cutaneous melanoma subtypes show different BRAF ans NRAS mutation frequencies. Hum Cancer Biol, v. 12, n. 15, p. 4499-505, 2006.

11. SHINOZAKI, M. et al. Incidence of BRAF oncogene mutation and clinical relevance for primary cutaneous melanoma. Clin Cancer Res, v. 10, p. 1753-7, 2004.

12. SMYTH, P. et al. ret/PTC and BRAF act as distinct molecular, time dependant triggers in a sporadic Irish cohort of papillary thyroid carcinoma. Int J Surg Pathol, v. 13, n. 1, p. 1-8, 2005.

13. THOMAS, N. E. et al. Tandem BRAF mutations in primary invasive melanomas. J Invest Dermatol, v. 122, p. 1245-50, 2004.

14. VIROS, A. et al. Improving melanoma classification by integrating genetic and morphologic features. PloS Medicine, v. 5, n. 6, p. e120, 2008.

Mailing adress

Juliana Elizabeth Jung Hospital Erasto Gaertner Serviço de Anatomia Patológica Rua Ovande do Amaral, 20 - Jardim das Américas CEP: 81520-060 - Curitiba-PR Tel.: (41) 3361-5000 Fax: (41) 3266-1822 e-mail: julianajung@onda.com.br 